(C) Elsevier/INRA

Original article

\title{
Effects of selection for early and late reproduction in low and high larval density populations of the bean weevil (Acanthoscelides obtectus)
}

\author{
I Gliksman, N Tucić * \\ University of Belgrade, \\ Institute for Biological Research and Faculty of Science, Yugoslavia
}

(Received 25 May 1990; accepted 30 November 1990)

\begin{abstract}
Summary - This study concerns an analysis of one-generation selection for early and late reproduction in populations maintained for 10 generations at low and high levels of larval density. We have obtained direct responses to selection in both the early and late reproducing parents. There was, however, no correlation between fecundity and longevity. Phenotypic responses suggest that parental age could change the fecundity schedule in the way predicted by antagonistic pleiotropy theory. However, the absence of statistically detectable negative genetic correlation between early and late fecundities made our study inconclusive with respect to possible genetically based trade-off among fecundity indices.

Acanthoscelides obtectus / larval density / parental age effect / fitness components

Résumé - Effets de la sélection pour une reproduction précoce et tardive dans des populations de bruche du haricot (Acanthoscelides obtectus) à haute et faible densité larvaire. Cette étude concerne l'analyse d'une génération de sélection pour une reproduction précoce ou tardive de populations maintenues pendant 10 générations à une densité larvaire faible ou élevée. Nous avons obtenu des réponses directes à la sélection, chez les parents à reproduction précoce et à reproduction tardive. Il n'y avait cependant pas de corrélation entre la fécondité et la longévité. Les réponses phénotypiques suggèrent que l'âge des parents pourrait modifier l'évolution de la fécondité au cours de la vie comme le prédit la théorie de la pléiotropie antagoniste. Cependant, l'absence de corrélation négative statistiquement détectable entre les fécondités précoces et tardives ne nous permet pas de conclure quant à des oppositions de nature génétique entre ces 2 fécondités.
\end{abstract}

Acanthoscelides obtectus / densité larvaire / âge des parents / valeur adaptative

* Correspondence and reprints: N Tucić, Institute of Zoology, Faculty of Science, PO Box 550, Studentski trg 16, 11000 Belgrade, Yugoslavia 


\section{INTRODUCTION}

Since natural selection operates on several traits simultaneously the optimal life history has been seen as "the best compromise given a set of options" (Sibly and Calow, 1986). Starting from this point, a great deal of the theory of life history evolution (see eg Charlesworth, 1980; Reznick, 1985; Scheiner et al, 1989) is based on the assumption of "trade-offs" or negative genetic pleiotropy among life history fitness components (fitness components are largely synonymous with life history parameters; see eg Istock, 1983). For example, according to the best-known evolutionary theory of senescence (Williams, 1957), senescence is envisaged most accurately as a by-product of genes with pleiotropic effects on the fitness components, such that increases early in the life span in one set of fitness components are accompanied by decreases in other fitness components later in life.

Despite the central position of antagonistic pleiotropy in life history theory, experimental demonstrations of genetic trade-offs were until very recently almost absent. Several recent studies (eg Rose and Charlesworth, 1981a, b; Rose, 1984; Luckinbill et al, 1984; Tucić et al, 1988) have provided evidence of negative genetic correlations among traits at early and late stages of life history. However, Giesel et al (1982), Stearns (1983), Mitchell-Olds (1986) and Engstrom et al (1989), for example, found no evidence of negative genetic correlations among fitness components.

Independently of any mechanism of genetic control proposed, the fundamental question of the evolutionary theory of senescence is "how do long and short life spans evolve?" (Luckinbill and Clare, 1985). Having in mind the suggestion provided by MacArthur and Wilson (1967) that density dependent selection could be responsible for much of the observed diversity of life history strategies among taxa, Luckinbill and Clare (1985) used 2 experimental treatments of larval density in a long-term selection study for increased longevity of Drosophila melanogaster. By selecting for late reproduction when larval density was held low, they were unable to detect a significant increase in longevity. However, populations with high and uncontrolled numbers of the developing larvae responded strongly to selection for late reproduction, with the longevity increasing by $\approx 50 \%$. Thus Luckinbill and Clare demonstrated, showing that the larval environment could alter the expression of genes for adult longevity, existence of genetic variation for sensitivity of fitness to density. Service et al (1988) have corroborated these findings. Indeed, low rearing density seems to reduce response to selection for increased longevity in Drosophila populations.

Motivated by these studies on Drosophila, as surprisingly little experimental work on genetic variation for response to conspecific density exists, we conducted an experiment to examine the phenotypic and genetic responses in bean weevil (Acanthoscelides obtectus) life history traits that occur when density dependent selection is acting. Specifically, in this paper we present the results of a study of one-generation selection for early and late reproduction in populations maintained for 10 generations at low and high levels of larval density. 


\section{MATERIALS AND METHODS}

\section{Life history of Acanthoscelides obtectus}

The bean weevil, Acanthoscelides obtectus (Say), is a well known leguminous-feeding beetle of the family Bruchidae (Coleoptera). The females lay eggs on the surface of host seeds. The eggs hatch, and the first instar larvae bore into the seed where they feed. The final instar larvae excavate a chamber just below the seed testa, and the presence of a larva may be detected by a small "window". Pupation occurs in this chamber and adults must chew a hole through the testa in order to emerge. Larval stages feed entirely within a single seed. Competition among larvae in overcrowded circumstances can be severe; from a single bean seed (about $20 \mathrm{~mm}$ sized) as many as 45 adults can emerge (personal observation). The adults do not require to feed in order to mate and oviposit. This feature (non-feeding adults) of the bean weevil life history is particularly attractive for the analysis of genetic trade-offs since adults have a finite amount of resource that may be allocated between fecundity and maintenance.

The population used here was "synthetic", originating from different local populations of Yugoslavia. It was maintained in culture $\approx 3 \mathrm{yr}$ prior to these experiments. In all experiments Phaseolus vulgaris cv "gradistanac" beans were used. The size of all seeds used in the present experiment was $\approx 20 \mathrm{~mm}$. All the beans were brought in bulk at one time from one source.

\section{Density dependent selection}

The following summarizes the method of selection used to obtain the low density, high density and control populations.

The low density regime was designed to be uncrowded for the developing larvae. At the start of this treatment, 320 beetles were chosen randomly from the base population and reared in 10 separate bottles with 100 bean seeds (ie each bottle contained 32 weevils whose sex ratio has been determined by chance). After $\approx 3$ wk these bottles were monitored daily until the first eclosion of adults began (the eclosion is recognized by getting "windows" black; otherwise windows at the seed testa are grey). At that time beans with 1 to 3 windows (which indicate low larval density) were separated. Since the probability of larvae from same bean being sibs is higher when the number of larvae per bean is small (which could cause inbreeding depression over generations) we employed the following procedure. Beans with low larval density from all 10 bottles were kept together in a single bottle. The seeds with higher larval density were discarded. From the newly emerged adults (usually $\approx 1000$ individuals), in the batch of low larval density seeds we chose, again randomly, 10 groups with 32 beetles, in order to establish a new generation. This procedure was repeated for 10 generations.

A high density population was maintained under high larval density. The procedure and propagule size ( $i e 32$ beetles per bottle) were as described above, except that new generations were founded from beans containing 10-20 (rarely more) windows. Thus, the only difference between the 2 selection regimes was the higher degree of larval crowding in the high density population. 
In the control treatment we did not control larval density. In all other aspects the experimental procedures were identical to those in the previous 2 treatments.

\section{Analysis of the parental age effects}

After 10 generations 200 pairs of beetles were chosen randomly from each treatment. Individual females were put into separate Petri dishes containing 3 beans and an unrelated male, for oviposition. These Petri dishes were checked daily. Upon death of the female, her life span and daily fecundity were recorded. In order to demonstrate parental age effects in the population selected for different larval density, the following 1-generation artificial selection for age-specific modification of fecundity was imposed.

This selection proceeded by choosing the females with highest 3-day fecundity record, from 1-3 as the "young" parents, and from 7-10 as the "old" parents. According to our previous results (Tucic et al, 1990) these 2 periods are the most convenient for analysing age-specific pattern of reproduction in the non-feeding bean weevils. Thus, within the population selected for different larval densities, the experiments were designed to enforce an early versus late age-specific pattern of reproduction. The best $25 \%$ of females laying were chosen. However, for late reproduction more intense selection was imposed $(\approx 15 \%$ of females laying were chosen as the parents) because of the low fecundity of the old females or some other reason.

Daily fecundity was measured on 4 newly emerged adult females, chosen at random from each selected female, in separate Petri dishes with 3 bean seeds and a male sib. The number of beetles which died was counted every day. Upon death of the female, her longevity and different fecundity indices have been recorded. We chose the following indices of fecundity: egg-laying d 1-3, egg-laying d 7-9, egglaying d 10 or more; total fecundity (over life span), first day of egg laying, last day of egg laying, age of peak fecundity and laying rate (total fecundity/last day of egg laying).

All cultures were maintained in an incubator at $30^{\circ} \mathrm{C}$ and $\approx 70 \%$ humidity. Experimental adults were subjected to starvation.

Narrow sense heritability for each trait was estimated by regression analysis of mean offspring values and maternal values (Falconer, 1981). In general, it is desirable to regress offspring values of the male parents, because the estimated covariance between mother and offspring can be inflated by maternal effects. Unfortunately, regression on male parent is impossible here because we analysed age-specific fecundity pattern in females. Thus, the confounding of maternal and genetic covariance in the parent-offspring regression is unavoidable. In addition, broad sense heritability was also calculated using a least squares analysis of variance model (Sokal and Rohlf, 1981).

\section{RESULTS}

In table I the means and standard errors of different life history traits for each density selected population in the first generation of reproduction at young or old age are given. For each trait pairwise comparisons between means were made 
Table I. Means $(\bar{X})$ and standard errors $(S E)$ for longevity and 8 fecundity indices in offspring of young and old parents within populations selected for low and high larval density.

\begin{tabular}{|c|c|c|c|c|c|c|c|c|c|c|c|c|}
\hline \multirow[t]{2}{*}{ Trait } & \multicolumn{4}{|c|}{ Control } & \multicolumn{4}{|c|}{ Low density } & \multicolumn{4}{|c|}{ High density } \\
\hline & & $\begin{array}{l}\text { Young } \\
\pm S E\end{array}$ & $\mathrm{n} \bar{X}$ & $\begin{array}{c}\text { Old } \\
\pm S E\end{array}$ & & $\begin{array}{l}\text { Young } \\
\pm S E\end{array}$ & & $\begin{array}{c}\text { Old } \\
\bar{X} \pm S E\end{array}$ & & $\begin{array}{l}\text { Young } \\
\pm S E\end{array}$ & $\mathbf{n} \bar{X}$ & $\begin{array}{c}\text { Old } \\
\bar{\Sigma} \pm S E\end{array}$ \\
\hline ongevity & 201 & $\begin{array}{r}15.56 \\
\pm 0.28\end{array}$ & 51 & $\begin{array}{l}15.71 \\
\pm 0.42\end{array}$ & 199 & $\begin{array}{r}14.65 \\
\pm 0.23\end{array}$ & 25 & $\begin{array}{r}15.20 \\
\pm 0.71\end{array}$ & 216 & $\begin{array}{r}12.83 \\
\pm 0.18\end{array}$ & 51 & $\begin{array}{r}13.47 \\
\pm 0.41\end{array}$ \\
\hline $\begin{array}{l}\text { ecundity } \\
\text { Days 1-3 }\end{array}$ & 201 & $\begin{array}{r}28.45 \\
\pm 1.39\end{array}$ & 51 & $\begin{array}{r}26.22 \\
\pm 2.71\end{array}$ & 199 & $\begin{array}{r}32 \\
\pm 1\end{array}$ & 25 & $\begin{array}{r}24.40 \\
\pm 4.57\end{array}$ & 216 & $\begin{array}{r}35.36 \\
\pm 1.10\end{array}$ & 51 & $\begin{array}{r}24.37 \\
\pm 2.94\end{array}$ \\
\hline Days 7-9 & 199 & $\begin{array}{r}3.48 \\
\pm 0.53\end{array}$ & 51 & $\begin{array}{r}5.16 \\
\pm 1.24\end{array}$ & 199 & $\begin{array}{r}3.67 \\
\pm 0.45\end{array}$ & 25 & $\begin{array}{r}4.04 \\
\pm 1.52\end{array}$ & 214 & $\begin{array}{r}2.83 \\
\pm 0.42\end{array}$ & 51 & $\begin{array}{r}6.57 \\
\pm 1.47\end{array}$ \\
\hline Days $\geq 10$ & 194 & $\begin{array}{r}6.61 \\
\pm 0.79\end{array}$ & 51 & $\begin{array}{r}8.16 \\
\pm 1.34\end{array}$ & 191 & $\begin{array}{r}5.52 \\
\pm 0.67\end{array}$ & 23 & $\begin{array}{r}10.77 \\
\pm 2.17\end{array}$ & 173 & $\begin{array}{r}2.71 \\
\pm 0.52\end{array}$ & 45 & $\begin{array}{r}4.67 \\
\pm 1.05\end{array}$ \\
\hline Total & 201 & $\begin{array}{r}52.00 \\
\pm 1.79\end{array}$ & 51 & $\begin{array}{r}52.73 \\
\pm 3.16\end{array}$ & 199 & $\begin{array}{r}55.95 \\
\pm 1.58\end{array}$ & 25 & $\begin{array}{l}49.04 \\
\pm 4.74\end{array}$ & 216 & $\begin{array}{l}57.37 \\
\pm 1.29\end{array}$ & 51 & $\begin{array}{r}44.96 \\
\pm 3.49\end{array}$ \\
\hline First day & 197 & $\begin{array}{r}2.43 \\
\pm 0.19\end{array}$ & 51 & $\begin{array}{r}2.51 \\
\pm 0.40\end{array}$ & 198 & $\begin{array}{r}2.11 \\
\pm 0.16\end{array}$ & 25 & $\begin{array}{r}4.12 \\
\pm 0.88\end{array}$ & 215 & $\begin{array}{r}1.69 \\
\pm 0.10\end{array}$ & 50 & $\begin{array}{r}3.18 \\
\pm 0.53\end{array}$ \\
\hline Last day & 197 & $\begin{array}{r}10.49 \\
\pm 0.32\end{array}$ & 51 & $\begin{array}{r}10.84 \\
\pm 0.53\end{array}$ & 198 & $\begin{array}{r}9.76 \\
\pm 0.28\end{array}$ & 25 & $\begin{array}{r}10.88 \\
\pm 0.66\end{array}$ & 215 & $\begin{array}{r}7.79 \\
\pm 0.20\end{array}$ & 50 & $\begin{array}{r}9.56 \\
\pm 0.41\end{array}$ \\
\hline $\begin{array}{l}\text { Age of peak } \\
\text { fecundity }\end{array}$ & 197 & $\begin{array}{r}4.79 \\
\pm 0.32\end{array}$ & 51 & $\begin{array}{r}5.58 \\
\pm 0.73\end{array}$ & 198 & $\begin{array}{r}4.41 \\
\pm 0.29\end{array}$ & 25 & $\begin{array}{r}6.84 \\
\pm 1.04\end{array}$ & 215 & $\begin{array}{r}3.41 \\
\pm 0.19\end{array}$ & 50 & $\begin{array}{r}5.73 \\
\pm 0.63\end{array}$ \\
\hline $\begin{array}{l}\text { Laying } \\
\text { rate }\end{array}$ & 197 & $\begin{array}{r}6.62 \\
\pm 0.32\end{array}$ & 51 & $\begin{array}{r}5.97 \\
\pm 0.56\end{array}$ & 198 & $\begin{array}{r}7.07 \\
\pm 0.28\end{array}$ & 25 & $\begin{array}{r}5.47 \\
\pm 0.74\end{array}$ & 215 & $\begin{array}{r}8.51 \\
\pm 0.25\end{array}$ & 50 & $\begin{array}{r}5.74 \\
\pm 0.58\end{array}$ \\
\hline
\end{tabular}

using Tukey's test. The high larval density population for both parental ages shows lower average longevity relative to the corresponding parental age in the low density groups, as well as in control populations. These differences are significant at the 0.01 level in all but 1 case (low density, young parents $v s$ high density, old parents). In all other cases the differences between average longevities are insignificant. In the high larval density population all fecundity indices, except the fecundity 7-9 days, were significantly different between the offspring of the young and old parents. However, when the same comparisons are made within low density or control populations, the picture which emerges is quite different. Here Tukey's test has shown that fecundity indices of the differently aged parents, except for the first day of laying within the low density population, are not detectably different from each other (table I). All the other comparisons show that fecundity indices of the young parent offspring in the high density population are most frequently statistically different from the other treatment.

It is worth considering the effect of larval density on the longevity and fecundity irrespective of the parental age. Table II compares the means of these life history traits, obtained after pooling of early and late-reproduced parents within 
Table II. Pooled (early and late reproduced parents) average and standard errors $(\bar{X} \pm S E)$ within low and high density populations. The signs of the $t$-test denote agreement $(+)$ or disagreement $(-)$ with prediction of $r$ - and $K$-selection theory.

\begin{tabular}{lcrrrr}
\hline \multirow{2}{*}{ Trait } & \multicolumn{2}{c}{ Low density } & \multicolumn{2}{c}{ High density } & \multirow{2}{*}{ t-test } \\
\cline { 2 - 5 } & $\mathrm{n}$ & $\bar{X} \pm S E$ & $\mathrm{n}$ & $\bar{X} \pm S E$ & \\
\cline { 2 - 5 } Longevity & 224 & 14.71 & 267 & 12.96 & $-6.43^{* *}$ \\
& & \pm 0.22 & & \pm 0.17 & \\
Fecundity & & & & & \\
Days 1-3 & 224 & 31.63 & 267 & 33.26 & -1.02 \\
& & \pm 1.22 & & \pm 1.05 & \\
Days 7-9 & 224 & 3.71 & 265 & 3.55 & -0.26 \\
& & \pm 0.43 & & \pm 0.44 & \\
Days $\geq 10$ & 214 & 6.02 & 218 & 3.11 & $-3.72^{* *}$ \\
& & \pm 0.63 & & \pm 0.46 & \\
First day & 223 & 2.33 & 265 & 1.97 & -1.68 \\
& & \pm 0.17 & & \pm 0.13 & \\
Last day & 223 & 9.89 & 265 & 8.12 & $-5.59^{* *}$ \\
& & \pm 0.26 & & \pm 0.18 & \\
Age of peak & 223 & 4.69 & 265 & 3.85 & $-2.43^{*}$ \\
fecundity & & \pm 0.29 & & \pm 0.19 & \\
Laying rate & 223 & 6.89 & 265 & 7.99 & $-3.16^{* *}$ \\
& & \pm 0.26 & & \pm 0.23 & \\
\hline
\end{tabular}

${ }^{*} P<0.05 ;{ }^{* *} P<0.01$.

populations with low and high larval densities. The average longevity, fecundity $\geq 10 \mathrm{~d}$, last $\mathrm{d}$ of egg laying, age of peak fecundity and laying rate were higher in the low density population than in the high density population. In all above cases the differences between traits at low and high density were significant, as shown by the $t$-test. The observed pattern among life history traits, for weevils selected for different larval density, is quite opposite to that predicted by $r$ - and $K$-selection regimes (see Pianka, 1970). An outcome such as we obtained is expected in models of life history in which the effects of variable environment are relatively greater on mortality of juveniles than adults. Stearns (1976) discusses these predictions under the heading of "bet-hedging".

It seems from table I that parental age at the time of reproduction can also affect the analysed traits. To test for significance between early and late-reproduced parents, taking simultaneously into account the effects of larval density, a 2-way analysis of variance was made (since we had an unbalanced data set, we used the method described in Steel and Torrie, 1960). The results of such an analysis of variance for longevity and different fecundity indices are presented in table III. In all these cases there was a small, statistically insignificant "parental age $\times$ density" interaction, suggesting that these 2 variables are largely independent in moulding the observed pattern among analysed traits. Interestingly enough, the effects of 
parental age and population density on longevity and fecundity seem to be different. For all fecundity indices we found significant influence of parental age (table III). Significant effects of larval density have been found for longevity, as well as for several fecundity indices (see table III).

Table III. Mean squares (MS) from 2-way ANOVA. Control population is not included. $d f_{e}=$ error degrees of freedom; dfs for all other MSs are 1 .

\begin{tabular}{|c|c|c|c|c|c|}
\hline \multirow{2}{*}{ Trait } & \multicolumn{5}{|c|}{ Source of variation } \\
\hline & & Parental age & $\begin{array}{c}\text { Population } \\
\text { density }\end{array}$ & Interaction & Error \\
\hline $\begin{array}{l}\text { Longevity } \\
\qquad d f_{e}=487\end{array}$ & $\begin{array}{l}\mathrm{MS} \\
\mathrm{F}\end{array}$ & $\begin{array}{r}20.45 \\
2.29\end{array}$ & $\begin{array}{l}393.18 \\
44.14^{* * *}\end{array}$ & $\begin{array}{l}0.12 \\
0.01\end{array}$ & 8.91 \\
\hline $\begin{array}{l}\text { Fecundity } \\
\qquad \begin{array}{l}\text { Days } 1-3 \\
d f_{e}=487\end{array}\end{array}$ & $\begin{array}{l}\text { MS } \\
\mathrm{F}\end{array}$ & $\begin{array}{l}5278.09 \\
\quad 16.74^{* * *}\end{array}$ & $\begin{array}{r}711.45 \\
2.26\end{array}$ & $\begin{array}{r}118.09 \\
0.38\end{array}$ & 315.28 \\
\hline $\begin{array}{l}\text { Days } 7-9 \\
d f_{e}=485\end{array}$ & $\begin{array}{l}\mathrm{MS} \\
\mathrm{F}\end{array}$ & $\begin{array}{c}243.73 \\
5.17^{*}\end{array}$ & $\begin{array}{r}16.27 \\
0.35\end{array}$ & $\begin{array}{r}163.87 \\
3.48\end{array}$ & 47.12 \\
\hline $\begin{array}{l}\text { Days } \geq 10 \\
d f_{e}=485\end{array}$ & $\begin{array}{l}\text { MS } \\
\text { F }\end{array}$ & $\begin{array}{c}571.25 \\
8.55^{* *}\end{array}$ & $\begin{array}{c}1088.69 \\
16.29^{* * *}\end{array}$ & $\begin{array}{r}93.62 \\
1.40\end{array}$ & 66.84 \\
\hline $\begin{array}{l}\text { Total } \\
d f_{e}=487\end{array}$ & $\begin{array}{l}\mathrm{MS} \\
\mathrm{F}\end{array}$ & $\begin{array}{c}5383.51 \\
\quad 11.94^{* * *}\end{array}$ & $\begin{array}{r}50.03 \\
0.11\end{array}$ & $\begin{array}{r}435.16 \\
0.97\end{array}$ & 450.82 \\
\hline $\begin{array}{l}\text { First day } \\
\quad d f_{e}=484\end{array}$ & $\begin{array}{l}\text { MS } \\
\mathrm{F}\end{array}$ & $\begin{array}{l}175.75 \\
32.36^{* * *}\end{array}$ & $\begin{array}{l}29.03 \\
5.35^{* *}\end{array}$ & $\begin{array}{l}3.88 \\
0.71\end{array}$ & 5.43 \\
\hline $\begin{array}{l}\text { Last day } \\
d f_{e}=484\end{array}$ & $\begin{array}{l}\text { MS } \\
\mathbf{F}\end{array}$ & $\begin{array}{l}119.83 \\
10.27^{* * *}\end{array}$ & $\begin{array}{l}423.00 \\
36.24^{* * *}\end{array}$ & $\begin{array}{l}6.06 \\
0.52\end{array}$ & 11.67 \\
\hline $\begin{array}{l}\text { Age of peak } \\
\text { fecundity } \\
\qquad d f_{e}=484\end{array}$ & $\begin{array}{l}\text { MS } \\
\mathrm{F}\end{array}$ & $\begin{array}{l}323.70 \\
23.21^{* * *}\end{array}$ & $\begin{array}{l}123.44 \\
8.85^{* *}\end{array}$ & $\begin{array}{l}0.17 \\
0.01\end{array}$ & 13.95 \\
\hline
\end{tabular}

Figure 1 shows the overall pattern of survivorships in different treatments. In order to compare different survivorship curves we have employed the test suggested by Rose (1984). This test is based on the comparison of mortality rates. Concerning mortality rate differences there are 2 hypotheses to test. First, statistical significance of the average mortality rate differences between paired groups. Second, analysis of trend with respect to age in mortality rate differences. The raw data for testing both hypotheses have been obtained as follows: (1), age specific mortality rates were calculated for each of 5 4-d intervals, from d 1 to d 20 of the assay (after d 20 there were too few individuals); (2), mortality rate differences between the paired groups have been divided by the total mortality rate in that age-interval; (3), the obtained data were then used to calculate the mean mortality rate differences between paired groups. Through each pair's mortality rate data the least square linear regression was calculated as well. 

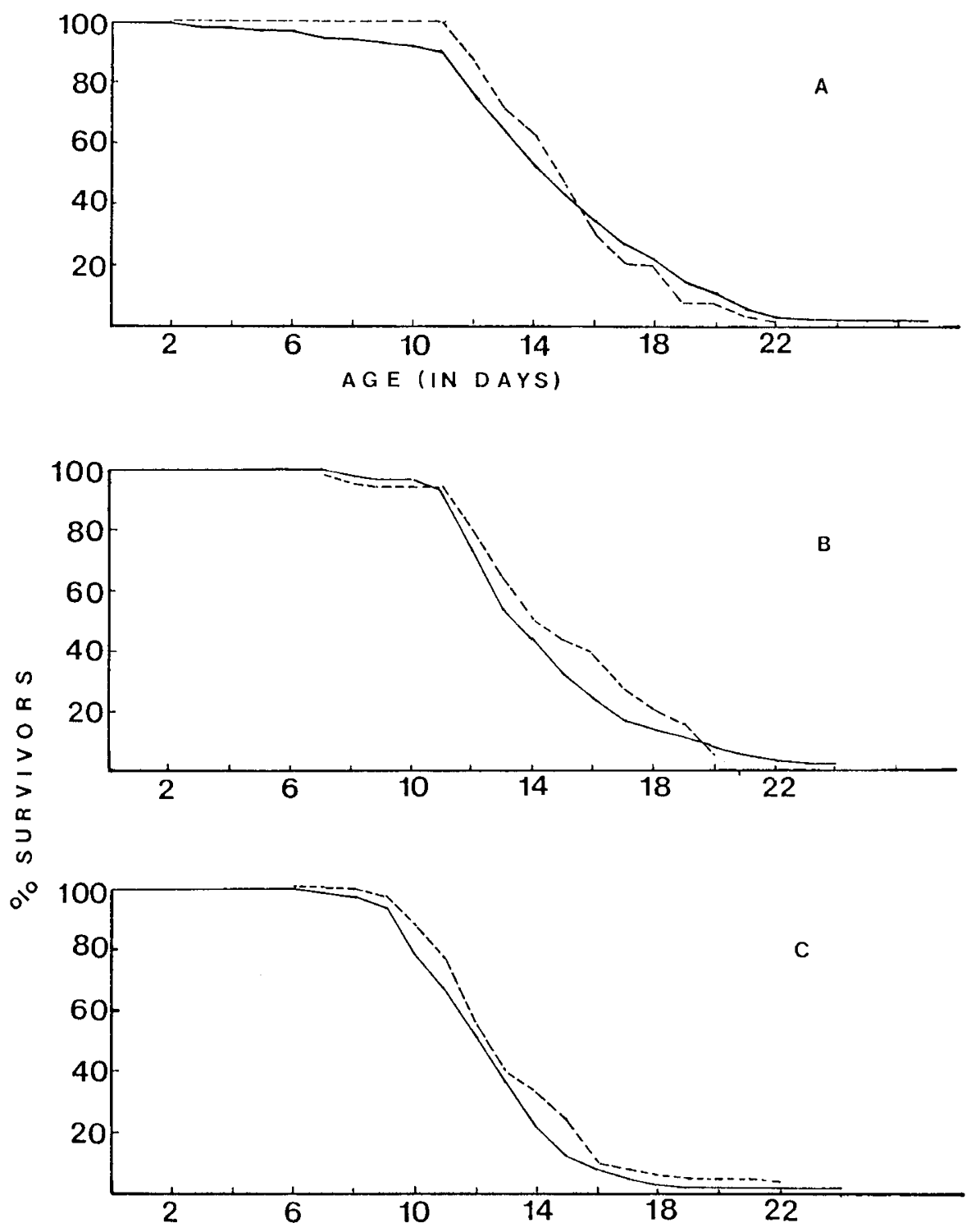

Fig 1. Survivorship of females selected for early and late (dashed lines) reproduction in control (A), low density (B) and high density (C) populations. 
None of the estimated average mortality rate differences between any pair of compared populations is significantly different from zero. In addition, except for the comparison within control population (between offspring of young and old parents) there is no apparent age specificity in mortality rate differences between compared groups. (Space considerations preclude the detailed presentation of these results, but they are available from the senior author.)

The overall patterns of the mean daily fecundity in all treatments are shown in figure 2. Although there is no appropriate statistical test for the entire fecundity pattern, it seems that postponement in reproductive output is present in the offspring of old relative to young parents in all treatments.

The magnitudes of the actual responses to one-generation selection for early and late fecundity in terms of the intensity of selection $(i)$, selection differentials $(S)$, selection response $(R)$ and realized heritability $\left(h^{2}\right)$ are given in table IV. The change in the expected phenotypic value in offspring as a result of one-generation selection that chiefly interests us here is the realized heritability. The patterns for both traits (early and late fecundities) suggest that realized heritabilities are greater in the high density population. A comparison of realized heritabilities between early and late reproduced groups indicates that realized heritabilities are higher for early fecundity in all experimental populations.

Table IV. Direct responses to 1-generation selection for early and late reproduction within 3 populations. Early fecundity=fecundity $1-3 \mathrm{~d}$; late fecundity=fecundity $7-9 \mathrm{~d}$; $i=$ intensity of selection; $S=$ selection differential; $R=$ selection response; $h^{2}=$ realized heritability.

\begin{tabular}{lclcrcc}
\hline Population & Parental age & Fecundity & $i$ & \multicolumn{1}{c}{$S$} & $R$ & $h^{2}$ \\
\hline Control & Young & Early & 1.253 & 15.410 & 4.367 & 0.2834 \\
& Old & Late & 1.843 & 8.962 & 1.618 & 0.1806 \\
Low density & Young & Early & 1.265 & 13.612 & 9.824 & 0.7217 \\
& Old & Late & 2.040 & 9.125 & 1.265 & 0.1386 \\
High density & Young & Early & 1.219 & 11.288 & 15.056 & 1.3339 \\
& Old & Late & 1.843 & 13.071 & 3.2018 & 0.2449 \\
\hline
\end{tabular}

Narrow and broad sense heritability estimates for longevity and fecundity data for early reproduced weevils within each population are given in table V. The heritabilities for late reproduced parents have been omitted, since a valid estimation of genetic variation with a small number of families (here 10-16 per population) is not possible. Only 2 traits, both within the low density population, showed significant narrow sense heritabilities (table V). Among all full-sib estimates of heritability 7 were significantly different from zero.

Genetical variation is a necessary prerequisite for the existence of genetic correlation between different traits. Since we found no significant heritabilities in most analysed traits, there was a small possibility of finding a significant genetic correlation among them. Nevertheless, we calculated the additive genetic correlation matrix (by means of the parental-offspring regression method; see Falconer, 1981) 

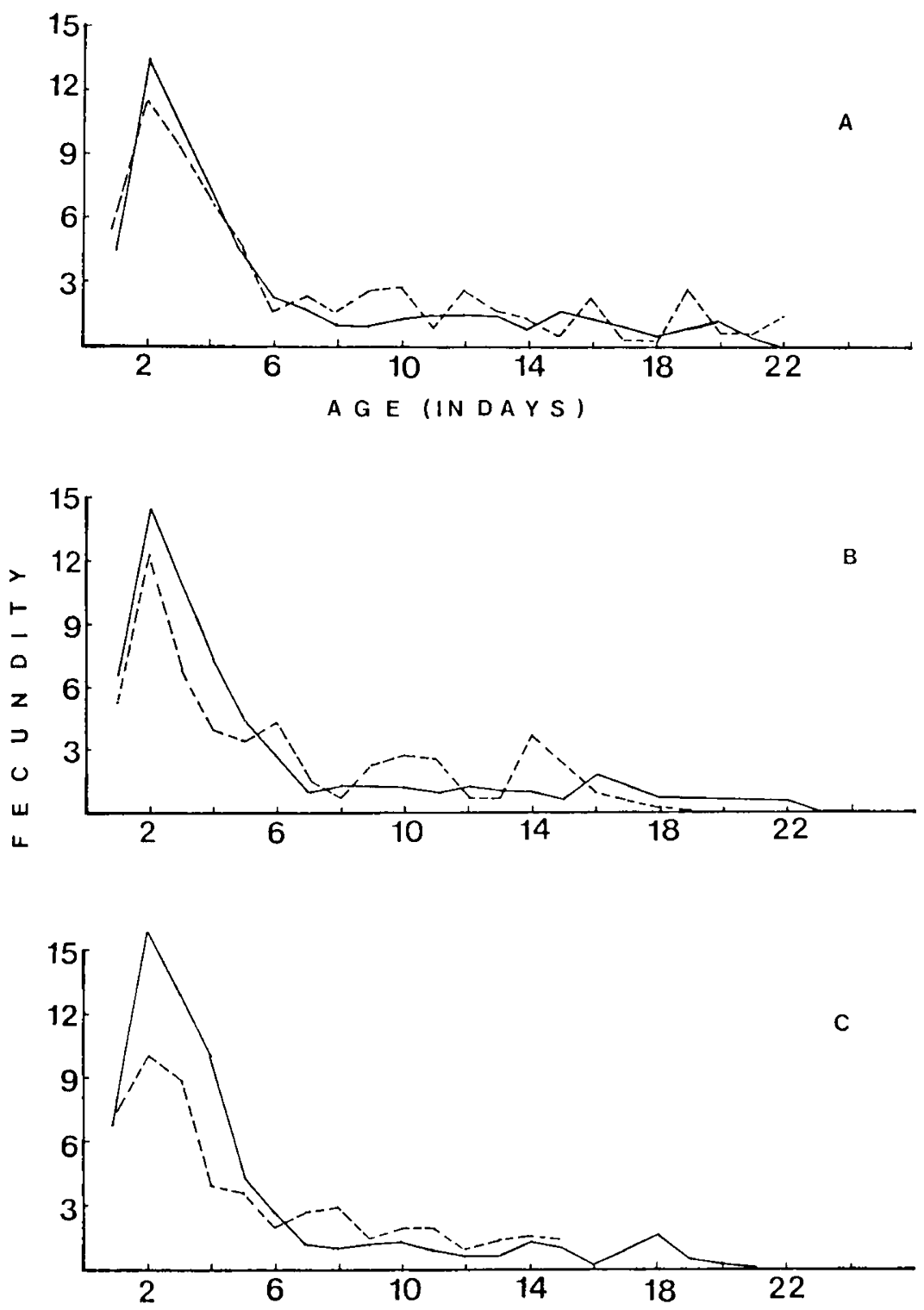

Fig 2. The mean daily fecundity of females selected for early and late (dashed lines) reproduction in control (A), low density (B) and high density (C) populations. 
Table V. Narrow $\left(h_{\mathrm{N}}^{2}\right)$ and broad sense $\left(h_{\mathrm{B}}^{2}\right)$ heritabilities and their standard errors $(S E)$ for early-reproduced weevils in the control, low- and high-density populations. Negative $h^{2}$ estimates are indicated by $-0 . \mathrm{N}=$ No of families.

\begin{tabular}{|c|c|c|c|c|c|c|}
\hline \multirow[t]{2}{*}{ Trait } & \multicolumn{2}{|c|}{ Control $(\mathbb{N}=52)$} & \multicolumn{2}{|c|}{ Low density $(\mathrm{N}=50)$} & \multicolumn{2}{|c|}{ High density $(\mathrm{N}=54)$} \\
\hline & $h_{\mathrm{N}}^{2} \pm S E$ & $h_{\mathrm{B}}^{2} \pm S E$ & $h_{\mathrm{N}}^{2} \pm S E$ & $h_{\mathrm{B}}^{2} \pm S E$ & $h_{\mathrm{N}}^{2} \pm S E$ & $h_{\mathrm{B}}^{2} \pm S E$ \\
\hline Longevity & $\begin{array}{r}0.21 \\
\pm 0.29\end{array}$ & $\begin{aligned} & 0.39^{* *} \\
\pm & 0.15\end{aligned}$ & $\begin{aligned} & 0.59^{*} \\
\pm & 0.22\end{aligned}$ & $\begin{array}{l}0.41^{* *} \\
\pm 0.15\end{array}$ & $\begin{array}{r}0.22 \\
\pm 0.21\end{array}$ & $\begin{aligned} & 0.50^{* *} \\
\pm & 0.15\end{aligned}$ \\
\hline $\begin{array}{l}\text { Fecundity } \\
\text { Days } 1-3\end{array}$ & $\begin{array}{r}0.90 \\
\pm 0.48\end{array}$ & $\begin{array}{r}0.14 \\
\pm 0.13\end{array}$ & $\begin{array}{r}1.06 \\
\pm 0.83\end{array}$ & $\begin{array}{c}0.30^{*} \\
\pm 0.14\end{array}$ & -0 & $\begin{array}{r}0.08 \\
\pm 0.12\end{array}$ \\
\hline Days $7-9$ & -0 & -0 & $\begin{array}{r}0.43 \\
\pm 0.29\end{array}$ & -0 & $\begin{array}{r}0.47 \\
\pm 0.52\end{array}$ & $\begin{array}{r}0.25 \\
\pm 0.14\end{array}$ \\
\hline Days $\geq 10$ & -0 & -0 & $\begin{array}{r}0.94 \\
\pm 2.08\end{array}$ & $\begin{array}{r}0.12 \\
\pm 0.14\end{array}$ & $\begin{array}{r}2.53 \\
\pm 3.53\end{array}$ & $\begin{array}{r}0.11 \\
\pm 0.15\end{array}$ \\
\hline Total & -0 & $\begin{array}{r}0.17 \\
\pm 0.14\end{array}$ & $\begin{array}{r}0.12 \\
\pm 0.36\end{array}$ & $\begin{aligned} & 0.45^{* *} \\
\pm & 0.15\end{aligned}$ & -0 & $\begin{array}{r}0.09 \\
\pm 0.12\end{array}$ \\
\hline First day & -0 & $\begin{array}{r}0.06 \\
\pm 0.13\end{array}$ & $\begin{array}{r}0.75 \\
\pm 0.59\end{array}$ & $\begin{array}{r}0.11 \\
\pm 0.13\end{array}$ & $\begin{array}{r}0.38 \\
\pm 0.41\end{array}$ & -0 \\
\hline Last day & $\begin{array}{r}0.22 \\
\pm 0.54\end{array}$ & $\begin{aligned} & 0.36^{*} \\
\pm & 0.15\end{aligned}$ & $\begin{array}{r}0.66 \\
\pm 0.37\end{array}$ & $\begin{array}{r}0.40 \\
\pm 0.15\end{array}$ & $\begin{array}{r}0.35 \\
\pm 0.23\end{array}$ & $\begin{array}{r}0.23 \\
\pm 0.13\end{array}$ \\
\hline $\begin{array}{l}\text { Age of peak } \\
\text { fecundity }\end{array}$ & $\begin{array}{r}0.43 \\
\pm 0.97\end{array}$ & -0 & -0 & -0 & $\begin{array}{r}0.65 \\
\pm 0.53\end{array}$ & $\begin{array}{r}0.40 \\
\pm 0.12\end{array}$ \\
\hline Laying rate & $\begin{array}{r}0.16 \\
\pm 0.31\end{array}$ & $\begin{array}{r}0.09 \\
\pm 0.13\end{array}$ & 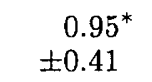 & $\begin{array}{r}0.42 \\
\pm 0.15\end{array}$ & -0 & $\begin{array}{r}0.25 \\
\pm 0.14\end{array}$ \\
\hline
\end{tabular}

${ }^{*} P<0.05 ;{ }^{* *} P<0.01$.

among traits for offspring of young parents within each of 3 populations. As predicted, none of the estimated correlations are significantly different from zero (for this reason we omitted their presentation, but they are available from the authors).

\section{DISCUSSION}

According to Luckinbill and Clare (1985) specific change in the external environment during preadult stages ( $i e$ high larval density) and the internal environment during adult stages ( $i e$ reproduction at the later stages) give rise to increased longevity in Drosophila melanogaster. The results of long-term selection for delayed senescence obtained by Rose and Charlesworth (1981b), Rose (1984), Mueller (1987) and Service et al (1988), also with $D$ melanogaster, are in qualitative accord with the above-cited expectation regarding the effects of parental age and larval density. It is to be expected, therefore, that 1-generation selection for late reproduction in a population selected 10 generations for high larval density will show higher longevity relative to a population selected for low larval density and early reproduction. In this experimental design with the bean weevil, Acanthoscelides 
obtectus, we, however, have not been successful in detecting significant response to combined effects of late parental age and high larval density with respect to adult longevity (table I).

In fact, we have obtained only direct responses to 1-generation selection in both early and late reproducing parents (table IV). However, there was no correlation between the fecundity responses and longevity. Though the average longevities in late reproduced parents suggest some enhancement in longevity, the overall effects of this treatment do not reveal significant differences (table III). Finally, mortality rate differences between treatments were not observed either.

The outcome of our previous study with the bean weevil (Tucić et al, 1990), in which long-term selection for early and late reproduction was imposed, has been consistent with the present results. Moreover, these findings are in agreement with the observation of Møller et al (1989), who found a similar relationship between longevity and fecundity in another weevil species, Calosobruchus maculatus. The absence of the direct link between fecundity and longevity in our experiments implies, therefore, that differences in fecundity of the bean weevils need not involve genes with pleiotropic effects on longevity.

Though quantitative genetic analyses seem futile when selection experiments fail to detect a cost of reproduction trade-off, we have found, at least, 2 reasons for such analyses. First, besides the predictive value, analyses of the genetic variation and covariation among fitness traits have important descriptive value. Second, and of more interest in the present context, there is a possibility that observed tradeoffs between early and late fecundity have a genetic basis. Indeed, the results in tables I and III suggest that parental age could really change the fecundity schedule in the way predicted by antagonistic pleiotropy theory (ie that offspring of the young parents have higher early fecundity than offspring of the old parents, and vice versa). But the absence of statistically detectable negative correlations between early and late fecundities made our study inconclusive with respect to the possible genetically based trade-off among fecundity indices. There is another argument against antagonistic pleiotropy between early and late fecundity. Having in mind our selection regimes, it is very likely that offspring of the young parents lack some genetic variants; increasing the late reproduction, which are present in offspring of the old parents. Similarly, the high late reproduction in offspring of the old parents would not be causally related to their low early reproduction effort (Partridge, 1987, has used the same arguments against negative genetic pleiotropy in the interpretation of the above-cited long term selection studies with Drosophila).

Hence, the simplest interpretation of our results is in terms of phenotypic plasticity for longevity and fecundity. It means that every bean weevil female may face a phenotypic (physiological) trade-off in the allocation of limited resources between fecundity and longevity, but in the absence of genetic variation in this allocation, the genetical trade-off is undetectable by long-term selection experiments or by genetical analyses. We could say then that differences between individuals are based on phenotypic plasticity (which is a short-term, contingent response of an individual to immediate circumstances which may increase fitness), and a genetical trade-off need not exist. 


\section{ACKNOWLEDGMENTS}

We thank D Marinkovic and the anonymous reviewers for their helpful suggestions and comments on the manuscript.

\section{REFERENCES}

Charlesworth B (1980) Evolution in Age-Structured Populations. Cambridge Univ Press, Cambridge

Engstrom G, Liljedahl EL, Rasmuson M, Bjorklund T (1989) Expression of genetic and environmental variation during ageing. I. Estimation of variance components for number of adult offspring in Drosophila melanogaster. Theor Appl Genet 77, $119-122$

Falconer DS (1981) Introduction to Quantitative Genetics. Longman, London Giesel JT, Murphy PA, Manlove MN (1982) The influence of temperature on genetic interrelationships of life history traits in a population of Drosophila melanogaster. What tangled data sets we weave. Am Nat 119, 464-479

Istock CA (1983) The extent and consequences of heritable variation for fitness characters. In: Population Biology, Retrospect and Prospect (King CE, Dawson PS, eds) Columbia University Press, New York

Luckinbill LS, Arking M, Clare MJ, Cirocco WC, Buck SA (1984) Selection for delayed senescence in Drosophila melanogaster. Evolution 38, 996-1003

Luckinbill LS, Clare M (1985) Selection for life span in Drosophila melanogaster. Heredity 55, 9-18

McArthur RH, Wilson EO (1967) The Theory of Island Biogeography. Princeton University Press, Princeton, NJ

Mitchell-Olds T (1986) Quantitative genetics of survival and growth in Impatiens capensis. Evolution 40, 107-116

Møller H, Smith RH, Sibly RM (1989) Evolutionary demography of a bruchid beetle. I. Quantitative genetical analysis of the female life history. Funct Ecol 3, 673-681 Mueller LD (1987) Evolution of accelerated senescence in laboratory populations of Drosophila. Proc Natl Acad Sci USA 84, 1974-1977

Partridge L (1987) Is accelerated senescence a cost of reproduction? Funct Ecol 1, 317-320

Pianka ER (1970) On $r$ - and $K$-selection. Am Nat 104, 592-597

Reznick D (1985) Cost of reproduction: an evaluation of the empirical evidence. Oikos 44, 257-267

Rose MR (1984) Laboratory evolution of postponed senescence in Drosophila melanogaster. Evolution 38, 1004-1010

Rose MR, Charlesworth B (1981a) Genetics of life history in Drosophila melanogaster. I. Sib analysis of adult females. Genetics $97,187-196$

Rose MR, Charlesworth B (1981b) Genetics of life history in Drosophila melanogaster. II. Exploratory selection experiments. Genetics 97, 187-196

Scheiner SM, Caplan RL, Lyman RF (1989) A search for trade-offs among life history traits in Drosophila melanogaster. Evol Ecol 3, 51-63

Service PM, Hutchinson EW, Rose MR (1988) Multiple genetic mechanisms for the evolution of senescence in Drosophila melanogaster. Evolution 42, 708-716 


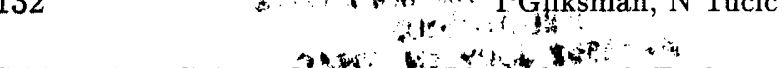

Sibly RM, Calow P (1986) Physological Ecology of Animals: An Evolutionary Approach. Blackwell Sci Publ, Oxford

Sokal RR, Rohlf FJ (1981) Biometry. Freeman, San Francisco, CA

Stearns SC (1976) Life-history tactics: a review of the ideas. $Q$ Rev Biol 51, 3-47

Stearns SC (1983) The genetic basis of differences in life history traits among six populations of mosquitofish (Gambusia affinis) that shared ancestors in 1905. Evolution 37, 618-627

Steel RGD, Torrie JH (1960) Principles and Procedures of Statistics. MacGraw-Hill, NY

Tucić N, Cvetković D, Milanović D (1988) The genetic variation and covariation among fitness components in Drosophila melanogaster females and males. Heredity 60, 55-60

Tucić N, Cvetković D, Stojiljković V, Bejaković D (1990) The effects of selection for early and late reproduction on fecundity and longevity in bean weevil (Acanthoscelides obtectus). Genetica 80, 221-227

Williams GC (1957) Pleiotropy, natural selection and the evolution of senescence. Evolution 11, 398-411 